Volume and Issues Obtainable at Center for Sustainability Research and Consultancy

Sustainable Business and Society in Emerging Economies

ISSN: 2708-2172 \& (E): 2708-2504

Volume 3: Issue 2 June 2021

Journal homepage: www.publishing.globalcsrc.org/sbsee

\title{
Growth of Micro, Small and Medium Enterprises (MSMEs) in MENA Countries: Constraints and Success Factors
}

Rim Ben Ayed Mouelhi, Professor, ISCAE, University of Manouba, LEFA, ERF and EMNES, Tunis, Tunisia

*Monia Ghazali, Senior Lecturer, IHEC, University of Carthage, LEFA, ERF and EMNES, Tunis, Tunisia

*Corresponding author's email address: monia.ghazali@ihec.u-carthage.tn

\begin{tabular}{l}
\hline ARTICLE DETAILS \\
\hline History \\
Revised format: May 2021 \\
Available Online: Jun 202 \\
\hline Keywords \\
Micro, small and medium \\
enterprises (MSMEs), \\
Growth, \\
Innovation, \\
Multinomial logit
\end{tabular}

JEL Classification M21, L2, M5

OPEN Orecss

\begin{abstract}
Purpose: This study attempts to contribute to a better understanding of the main constraints/ boosters for MSME growth in selected countries of the MENA region (Tunisia, Egypt, Morocco and Jordan).

Design/Methodology/Approach: A multinomial logit model is used to investigate the impact of a three-fold classification of firm growth determinants (company characteristics, manager characteristics and business environment characteristics). The database is provided by the World Bank Enterprise Surveys (MENA ES).
\end{abstract}

Findings: Results give statistically robust evidence that innovative firms are more likely to grow.

Implications/Originality/Value: Therefore, the implementation of efficient and well-governed systems of innovation is a priority in the MENA region.

(C) 2021 The authors, under a Creative Commons AttributionNonCommercial- 4.0

Recommended citation: Mouelhi, R. B. A. and Ghazali, M. (2021). Growth of Micro, Small and Medium enterprises (MSMEs) in MENA countries: constraints and success factors. Sustainable Business and Society in Emerging Economies, 3 (2), 59-73

\section{Introduction}

One of the most stylized facts emphasized in the EMNES study (2017) regarding the private sector development in the selected MENA region countries (Tunisia, Egypt, Morocco and Jordan) is that micro and very small firms are overwhelming in numbers, though they make the smallest contribution to job creation, as well as limited upward mobility, (The World BankTunisia Development Policy Review, (2015); the World Bank Group business climate report on MENA region, (2016)). Micro and small firms do not seem to grow. They are the least productive and the least innovative, since they do not have the appropriate financial, human and logistical resources. In Tunisia, for example, micro firms represent $98 \%$ of firms, however, they generate only $16 \%$ of employment. Meanwhile, the share of small and medium firms within the 
total number of private firms is relatively small (around one percent). Yet, SMEs absorb about $42 \%$ of total employment.

To sum up, the private sectors in the MENA countries are characterized by the "missing Middle" phenomenon. The development of small and medium businesses through the support of micro firms' growth can foster the dynamic of job creation and contribute to poverty alleviation.

The literature on the MENA region private sector is relatively scarce. The purpose of this working paper is to empirically identify the main constraints/ boosters for MSME growth in selected countries of the MENA region (Tunisia, Egypt, Morocco and Jordan). We devise a theoretical and empirical analysis to spot the key growth factors. Firms are distinguished according to their growth rate. We consider three categories: fast growing enterprises (average growth rate $>=20 \%$ ) often referred to as "Gazelles", firms with a moderate growth rate (between $10 \%$ and $20 \%)$ and low-growth firms $(<10 \%)$. The aim is to capture the main differences and to learn from the experience of those MSMEs which were able to grow.

However, beyond the conventional constraints met by MSME companies related to the business environment (administrative procedures, taxes, infrastructure, access to finance) and the characteristics of firms (age, size, activity, innovation activities, etc.), we aim to focus on factors related to management competence, entrepreneurial experience and managerial skills. These factors are critical to the growth of small businesses, yet insufficiently investigated to date in the literature. Furthermore, we attempt to assess the innovation impact on MSME growth given that innovative firms have a greater probability of surviving and growing over the long term (Harrison, 2008).

The Database is provided by the World Bank Enterprise Surveys (MENA ES). It includes firmlevel data collected through interviews of business owners and top managers. The data covers a broad range of firm characteristics, as well as some characteristics of leaders and business environment issues, including: access to finance, corruption, infrastructure, competition, innovation and performance measures. The Enterprise Survey data is available for the four selected countries (Tunisia, Egypt, Morocco and Jordan). The firms' sample covers around 4469 firms, after cleansing.

The results of the empirical investigation will enable us to set a number of recommendations and priorities to support the growth of micro and small firms in the respective countries, in order to build a functioning private sector and to enhance job creation.

The first section of this study ${ }^{1}$ presents a literature review regarding the determinants of MSME growth. Section 2 draws a brief overview of the stylized facts on the MENA private sector. Section 3 is dedicated to the empirical strategy. Section 4 presents the main results and recommendations.

\section{Determinants of MSMEs Growth}

This section involves a literature review regarding the determinants of MSME performance growth. A wide range of studies, as Hampel et al. (2014), emphasize the constraints and success factors impacting the upgrading of MSMEs. The "onion model" of Reeg (2013) synthesizes a combination of these internal and external factors: entrepreneur characteristics, personal and professional networks, enterprise characteristics and business environments.

${ }^{1}$ This paper has been produced with the financial assistance of the European Union within the context of the EMNES project. The contents of this document are the sole responsibility of the authors and can under no circumstances be regarded as reflecting the position of the European Union or the EMNES Network. 
The entrepreneur characteristics and networks matter substantially in enterprise upgrading. Recently, Reeg (2013) and Hampel et al. (2014) have clearly shown that factors related to the competence of the entrepreneur and its human and social capital are critical to the growth of businesses. These factors are rarely mentioned by leaders when they are interviewed about the constraints to growth. However, the profile of business leaders, their entrepreneurial experience, their managerial skills, their attitudes, their ability to take risks, their knowledge of different sectors and their social capital and networks are crucial in research, as it might capture growth opportunities. A well-developed network can even facilitate the access to finance (Eifert, Gelb and Ramachandran (2005), Mouelhi (2001)).

The Firm characteristics: the age and size of the firm, as well as its location, the sector in which it operates, its human resources and skills, its absorption capacity and the ability to innovate are considered by several studies to be crucial for a firm's growth and prosperity. According to Jovanovic (1982), the oldest companies develop more slowly because their managers have already reached their most effective operational capacity. Most of the time, they have also reached their optimum productivity.

The size of the company might also be a critical factor. Small-sized companies are often lacking the resources to invest in new equipment, to innovate or to develop R\&D activities, which negatively impact their ability to grow (Rothwell and Dodgson, 1991). However, companies well-endowed with skilled and competent labour that invest in training and human resources development, are more likely to grow.

The owner's gender might also have an impact on a firm's growth. As indicated by Liedholm (2001), female owners would be more risk averse and probably less concerned by the firm's growth than male owners.

The degree of foreign cooperation and the technological absorption capacity of the firm are also important for its growth. Participating in export markets and developing partnerships with foreign investors provide firms with opportunities to open up to international best practices. It also fosters learning, improves efficiency and productivity and offers growth opportunities for the firm.

Furthermore, companies in urban zones grow more quickly than their rural counterparts, according to Liedholm (2001). They benefit from externalities of urban areas and large-scale markets.

The innovation effort: several studies have addressed the relationship between innovation and firm growth without reaching a consensus. Many theoretical studies (Aghion et al. (2005), Harrison and al (2008), Hall et al (2008)) have concluded there is a positive relationship between innovation and growth. Empirical studies have delivered mixed results. Some researchers emphasize the absence of a relationship between innovation and firm growth while others conclude that it is a positive association. One possible explanation of such a discrepancy is the different measures and various innovation components (product innovation, process innovation, etc.) considered, as well as the data and econometric methods used. One should also keep in mind that the impact of innovation on growth could be low or absent in the short-term, as it needs maturity and time to turn into firm growth. Furthermore, the relationship between firm growth and innovation could be bi-directional. Innovation is a key driver of growth. Yet, highgrowth firms have more resources and capacity to innovate (Mason and al, 2009). 
These things considered, there is almost a consensus on the fact that innovative firms have more probability of surviving and of growing in the long term. There is also a consensus on the positive impact of product innovations on growth. Product innovations have a positive impact on firm employment as they lead to an increase in new products sales and to market extension (Harrison et al (2008), Bianchini et al (2014)).

However, the impact of the innovation process on employment growth is variable and inconclusive. On one hand, the innovation process might improve the production process. It is expected to exert a positive impact on productivity via a more efficient use of factors, which could lead to a reduction in employment requirements and to a labour shrinkage. ${ }^{2}$ On the other hand, a compensation effect might take place: the innovation process leads to a decrease in production costs, and thus, in product price which translate into an increase in product demand and sales.

The business environment: Many studies show that the quality of the business environment is a determinant for MSME growth. Obstacles to firm growth range from political instability, hindered access to finance, regulation rigidity and heavy administrative procedures to corruption practices and unfair competition from the informal sector (Eifert et al (2005), MENA study (2017)).

\section{Data Description}

We use firm level data provided by the World Bank Enterprise Survey. Face to face interviews have been carried out with business owners and top managers in 2013 across 8 MENA countries $^{3}$. The MENA ES offers a representative sample of the non-agricultural, formal private sector. Firms included in the survey have at least five employees and operate in the manufacturing or services sectors ${ }^{4}$. According to the World Bank Report (2016), the survey has used random sampling, itemized by firm size, sector of activity, and regional location within each economy, as well as weighing which guarantees a statistical representation of the private sector for each country. Data covers a broad range of firm characteristics, including innovation, performance measures, leadership characteristics and business environment issues, such as access to finance, corruption, infrastructure, informal sector, competition, etc.

For the purpose of this study, we have extracted a sample of 4469 firms belonging to the countries of interest. Table 1 provides some descriptive statistics related to the data in use. The largest sub-sample was observed in Egypt. Firms mainly operate in the manufacturing sector. Furthermore, one can observe that small firms comprise by far the largest category (about 60\%) which is representative of the private sector structure in MENA countries.

We compute the average annual labour growth rates between 2009 and 2012 using the available data. As shown in Table 1, around $67 \%$ of firms have been downsizing, shrinking their number of employees. This is most notable in Tunisia and Egypt due to political, social and economic instability related to the popular uprisings. The so-called "gazelles", i.e., firms with an average annual growth rate exceeding $20 \%$, represent only $5.5 \%$ of total firms.

${ }^{2}$ This is infrequent according to Harrison et al (2008).

${ }^{3}$ Djibouti, Egypt, Jordan, Lebanon, Morocco, Tunisia, West Bank and Gaza and Yemen.

${ }^{4}$ Further details about The MENA Enterprise Survey are provided by the World Bank Report (2016). 
Table 1. Sample Description

\begin{tabular}{|l|l|l|l|l|l|}
\cline { 2 - 6 } \multicolumn{1}{c|}{} & \multicolumn{1}{c|}{ Tunisia } & \multicolumn{1}{c|}{ Morocco } & Egypt & \multicolumn{1}{c|}{ Jordan } & \multicolumn{1}{c|}{ Total } \\
\hline Firms number & 592 & 407 & 2897 & 573 & 4469 \\
\hline Size in 2009 & & & & & \\
Small (less than 50) & $\mathbf{5 9 \%}$ & $\mathbf{6 1 \%}$ & $\mathbf{5 5 \%}$ & $\mathbf{6 0 \%}$ & $\mathbf{5 7 \%}$ \\
Medium (50 to 200) & $26 \%$ & $23 \%$ & $19 \%$ & $17 \%$ & $20 \%$ \\
Large (above 200) & $15 \%$ & $16 \%$ & $26 \%$ & $23 \%$ & $23 \%$ \\
\hline Sectors & & & & & \\
Manufacturing & $56 \%$ & $51 \%$ & $71 \%$ & $66 \%$ & $\mathbf{6 7 \%}$ \\
Services & $34 \%$ & $29 \%$ & $24 \%$ & $20 \%$ & $25 \%$ \\
Retail & $10 \%$ & $20 \%$ & $5 \%$ & $14 \%$ & $8 \%$ \\
\hline Labor growth & & & & & \\
Less than 0 & $\mathbf{5 7 \%}$ & $47 \%$ & $\mathbf{7 7 \%}$ & $45 \%$ & $\mathbf{6 7 \%}$ \\
0 to 0.2 & $35 \%$ & $44 \%$ & $19 \%$ & $47 \%$ & $27.5 \%$ \\
above 0.2 & $8 \%$ & $9 \%$ & $4 \%$ & $8 \%$ & $5.5 \%$ \\
\hline
\end{tabular}

Source: Authors' compilation using the MENA ES database

\section{Stylized Facts on MSMEs in the MENA Countries}

\section{Micro Firms: The Major Category and The Creator of Least Jobs}

In Tunisia, according to the EMNES study (2017), firm size distribution is biased towards micro firms (98\% of total firms), which only absorb $16 \%$ of total employment (see figure 1). In turn, large firms employing more than 200 workers account for only $0.1 \%$ of all firms, but absorb $42 \%$ of total employment. Overall, medium or large firms with more than 50 workers account for more than $50 \%$ of total employment.

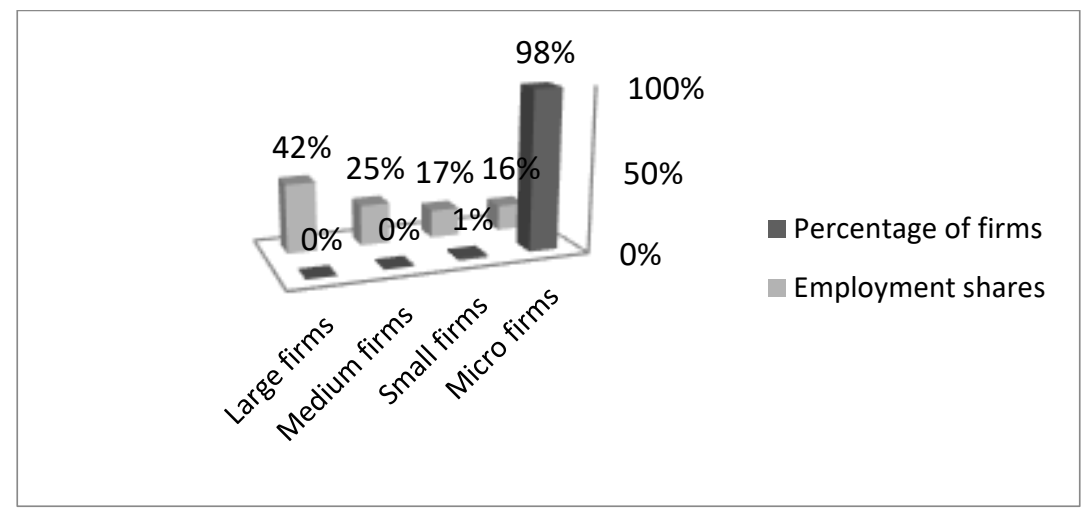

Figure 1. Employment Shares of Tunisian Firms in 2014 (sorted by size)

Source: Authors' compilation using RNE database. Micro firms employ less than 10 workers. Small firms employ between 10 and 50 workers. Medium firms account for between 50 and 200 workers. Large firms account for more than 200 workers.

In Jordan, the EMNES study (2017) points out that $89 \%$ of private sector establishments are micro enterprises and contribute to $36 \%$ of employment in the private sector. Nine percent of the firms can be considered small and employ a share of $16 \%$, while medium firms represent one percent of total firms but create $12 \%$ of total jobs. Large companies represent $0.5 \%$ of the total establishment but generate $36 \%$ of jobs. 


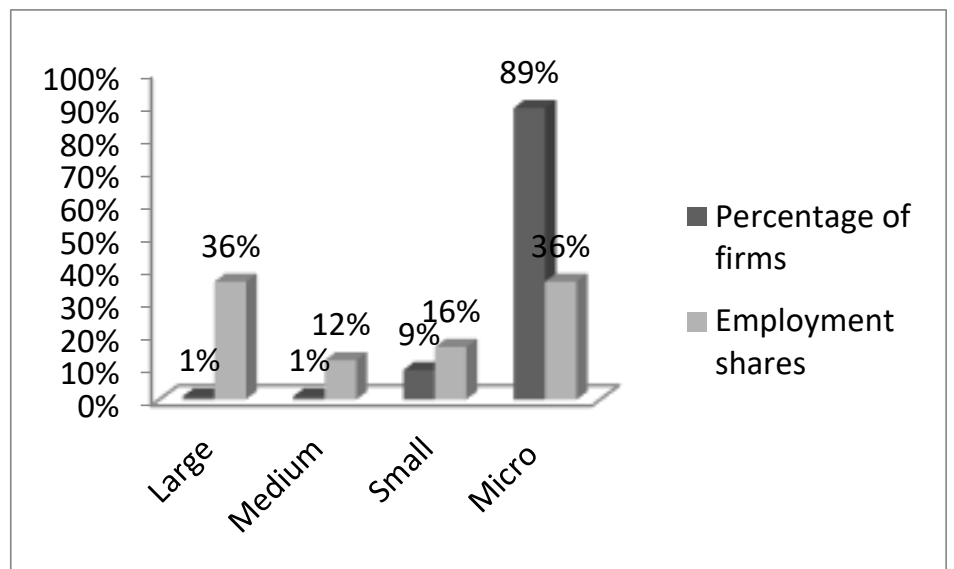

Figure 2. Employment Shares of Jordanian firms in 2013 (sorted by size)

Source: data from DoS, Employment Survey, 2004. Micro firms employ less than 5 workers. Small firms employ between 5 and 49 workers. Medium firms account for between 50 and 100 workers.

In Egypt, the EMNES study (2017) emphasizes that micro enterprises employing one to four employees constitute approximately $91 \%$ of all firms. Small and medium ones, employing between five and one hundred people, account for around eight percent, while large enterprises represent less than one percent.

According to the ERF Research Report (2016), micro firms employing less than ten workers constitute $97.7 \%$ of the MSE sector (employing less than 50 employees) in Morocco which, in turn, represents $99.6 \%$ of the non-agriculture private sector.

Although it is somewhat harsh to rely on comparable statistics for the four MENA countries, one could point out that the share of SMEs is small compared to micro firms, however they contribute significantly to employment. Overall, promoting the upgrading and expansion of micro firms would boost the SMEs sector and generate spillover effects to the economy as a whole.

\section{Limited Upward Mobility: SMEs Do Not Grow}

According to the employment transition matrix related to the four MENA countries of interest (see Table 2), 91\% of firms considered as small in 2009, remained small in 2012. None of the firms that had been categorized small in 2009 became large by 2012. Furthermore, only $4.5 \%$ of the firms that had been medium-sized in 2009 expanded in 2012, to become large companies. However, 36\% of large firms in 2009 shrunk, becoming medium or small-sized. Hence, the dynamism of firms is limited in the MENA region, probably due to distorted competition and discrimination in firms' access to government support, where there is a bias towards the selection and learning processes underlying firms' growth (ERF Research Report (2016)).

Table 2. Employment Transition Matrix MENA Countries, 2009-2012

\begin{tabular}{|l|l|l|l|l|}
\cline { 2 - 5 } \multicolumn{1}{c|}{} & \multicolumn{4}{c|}{ Size in 2012 } \\
\hline Size in 2009 & Large & Medium & Small & Total \\
& & & & \\
\hline Large & 927 & 215 & 320 & 1462 \\
& $63.4 \%$ & $14.7 \%$ & $21.9 \%$ & $100 \%$ \\
\hline Medium & 69 & 1225 & 200 & 1494 \\
& $4.6 \%$ & $82 \%$ & $13.4 \%$ & $100 \%$ \\
\hline Small & 6 & 132 & 1375 & 1513 \\
\hline
\end{tabular}




\begin{tabular}{|l|l|l|l|l|}
\hline & $0.4 \%$ & $8.7 \mathrm{M}$ & $90.9 \%$ & $100 \%$ \\
\hline Total & 1002 & 1572 & 1895 & 4.469 \\
& 22.4 & 35.1 & 42.4 & 100 \\
\hline
\end{tabular}

Source: Authors' computations using the MENA ES database

\section{Obstacles to MSME Development in MENA Countries}

According to figure 3, political instability is the major obstacle to MSME development, disclosed by firm managers in both Tunisia (50\%) and Egypt (48\%), due to the climate of uncertainty and political unrest following the popular uprisings. It is also among the top three cited obstacles in Jordan (12\%), as a consequence of regional instability. However, in Morocco, corruption is viewed as the main business environment constraint, by $19 \%$ of firms. In Jordan, the largest issue faced by firms is related to tax rates (17\% of respondents).

Access to finance is one of the top constraints jointly pointed out by managers in the four countries of interest. While the World Bank Report (2016) draws attention to the large size of financial and banking sectors in the MENA region, it emphasizes issues such as biased bank lending towards large firms and high collateral standards. Getting credit is a common issue pointed out by the latest World Bank's Doing Business Report (2017) in Morocco, Tunisia, Jordan and, to a lesser extent, Egypt (see Table 3). Informality and the inadequate workforce are commonly highlighted by both Morocco and Tunisia as important constraints to MSME growth, while an unreliable supply of electricity is one of the top concerns of Egyptian firms, confirmed by the Doing Business Report (2017). The same report ranked Egypt and Jordan badly (respectively $122^{\text {nd }}$ and $118^{\text {th }}$ among 190 countries) with regard to the ease of doing business far behind Morocco $\left(68^{\text {th }}\right)$ and Tunisia $\left(77^{\text {th }}\right)$. However, new entrepreneurs are facing greater challenges when starting a business in either Jordan or Tunisia $\left(103^{\text {rd }}\right.$ and $106^{\text {th }}$ out of $\left.190^{\text {th }}\right)$.

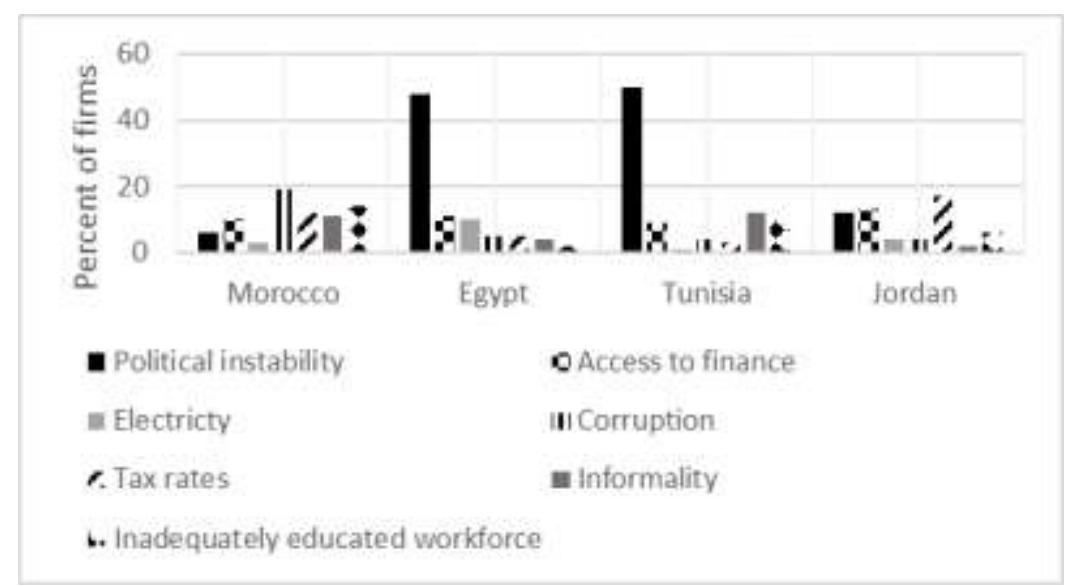

Source: MENA ES database

Figure 3. Obstacles to MSME Growth in MENA Countries

Table 3. MENA Countries Ranking Among 190 Countries (2017)

\begin{tabular}{|l|l|l|l|l|}
\cline { 2 - 5 } \multicolumn{1}{c|}{} & Egypt & Jordan & Morocco & Tunisia \\
\hline Ease of doing business & 122 & 118 & 68 & 77 \\
\hline Starting a business & 39 & 106 & 40 & 103 \\
\hline $\begin{array}{l}\text { Dealing with construction } \\
\text { permits }\end{array}$ & 64 & 109 & 18 & 59 \\
\hline Getting electricity & 88 & 48 & 57 & 40 \\
\hline Registering property & 109 & 96 & 87 & 92 \\
\hline Getting credit & 82 & 185 & 101 & 101 \\
\hline Protecting investors & 114 & 165 & 87 & 118 \\
\hline Paying taxes & 162 & 79 & 41 & 106 \\
\hline Trading abroad & 168 & 50 & 63 & 92 \\
\hline Enforcing contracts & 162 & 124 & 57 & 76 \\
\hline
\end{tabular}




\begin{tabular}{|l|l|l|l|l|}
\hline Closing a business & 109 & 142 & 131 & 58 \\
\hline
\end{tabular}

Source: World Bank’s Doing Business Report (2017)

\section{Empirical Analysis}

The purpose of this section is to assess the determinants of MSME growth in the MENA region. The dependent variable "Growth" is a multinomial variable with three outcomes. It takes the value of one if the firm registered a growth rate exceeding $20 \%$, rating it in the "gazelles" category. It takes the value of two with a growth rate of between $10 \%$ and $20 \%$. If the firm has grown by less than $10 \%$ per year on average during the last three years, the dependent variable takes the value of three. In order to compute the annual average growth rate $\mathrm{g}^{5}$ of MSMEs, we consider data regarding the number of employees in 2009 and 2012 as follows:

$$
\left\{\begin{array}{ccc}
\text { Growth }=1 & \text { if } & \mathrm{g} \geq 20 \% \\
\text { Growth }=2 & \text { if } & 10 \% \leq \mathrm{g}<20 \% \\
\text { Growth }=3 & \text { if } & \mathrm{g}<10 \%
\end{array}\right.
$$

We attempt to explain the propensity of a firm to grow by using a multinomial model with a broad set of explanatory variables, derived from a literature overview and available on the ES database. Table 4, below, sums up the main variables considered in the model.

Table 4. Variables Description

\begin{tabular}{|c|c|c|}
\hline \multicolumn{3}{|l|}{ Dependent variable } \\
\hline Growth & Multinomial variable & $\begin{array}{l}\text { 1: if the firm has grown by at least } 20 \% \\
\text { per year on average during the last } \\
\text { three years. } \\
\text { 2: if the firm has had a growth rate of } \\
\text { between } 10 \% \text { and } 20 \% \text {. } \\
\text { 3: if the firm has grown by less than } \\
10 \% \text {. }\end{array}$ \\
\hline \multicolumn{3}{|l|}{ Explanatory variables } \\
\hline \multicolumn{3}{|l|}{ Manager characteristics } \\
\hline Female Top manager & Binary variable & $\begin{array}{l}1: \text { if the manager is a woman } \\
0: \text { otherwise }\end{array}$ \\
\hline Top manager experience & Quantitative variable & $\begin{array}{l}\text { Manager's years of experience in the } \\
\text { same sector }\end{array}$ \\
\hline Owner Manager & Binary variable & $\begin{array}{l}\mathbf{1}: \text { if the manager is also owner of the } \\
\text { firm } \\
\mathbf{0}: \text { otherwise }\end{array}$ \\
\hline \multicolumn{3}{|l|}{ Firm characteristics } \\
\hline Firm size & Quantitative variable & $\begin{array}{l}\text { Number of formal workers by the end } \\
\text { of fiscal year } 2009 \text {. }\end{array}$ \\
\hline Firm age & Quantitative variable & Firm age in 2009 \\
\hline Government participation & Quantitative variable & The share of capital held by the state \\
\hline Foreign participation & Quantitative variable & $\begin{array}{l}\text { The share of capital held by private } \\
\text { foreign individuals, companies or }\end{array}$ \\
\hline
\end{tabular}

$5 \mathrm{~g}=\left[\left(\frac{\text { Workers_2012 }}{\text { Workers_2009 }}\right)^{1 / 3}-1\right]$ 


\begin{tabular}{|c|c|c|}
\hline & & organizations \\
\hline Innovation & Binary variable & $\begin{array}{l}\text { 1: If the firm has created or } \\
\text { significantly improved } \\
\text { product/service and/or if the firm has } \\
\text { adopted or significantly improved its } \\
\text { management practices and/or if the } \\
\text { firm has adopted or significantly } \\
\text { improved a new marketing strategy } \\
\text { and/or if the firm has created or } \\
\text { significantly improved logistics and } \\
\text { distribution methods and/or if the } \\
\text { firm has created or significantly } \\
\text { improved the production processes } \\
\text { over the period } 2009-2012 \\
\text { 0: Otherwise }\end{array}$ \\
\hline Productivity $(\mathrm{t}-3)$ & Quantitative variable & $\begin{array}{l}\text { Total annual sales in } 2009 / \text { Number of } \\
\text { formal workers by the end of the fiscal } \\
\text { year } 2009\end{array}$ \\
\hline Sales & Quantitative variable & Total annual sales \\
\hline \multicolumn{3}{|l|}{ Business Environment } \\
\hline Major obstacle Finance & Binary variable & $\begin{array}{l}\text { 1: if access to financing is considered } \\
\text { as a major obstacle } \\
\text { 0: otherwise }\end{array}$ \\
\hline $\begin{array}{lll}\text { Major } & \text { obstacle } & \text { Political } \\
\text { instability } & & \end{array}$ & Binary variable & $\begin{array}{l}\text { 1: if political instability is considered } \\
\text { as a major obstacle } \\
\text { 0: otherwise }\end{array}$ \\
\hline Major obstacle Workforce & Binary variable & $\begin{array}{l}\text { 1: if an inadequately educated } \\
\text { workforce is considered as a major } \\
\text { obstacle } \\
\text { 0: otherwise }\end{array}$ \\
\hline Major obstacle Licence & Binary variable & $\begin{array}{l}\text { 1: if getting a business licence or } \\
\text { permits is considered as a major } \\
\text { obstacle } \\
\text { 0: otherwise }\end{array}$ \\
\hline Capital city & Binary variable & $\begin{array}{l}\text { 1: if the city is the official capital city } \\
\text { 0: otherwise }\end{array}$ \\
\hline
\end{tabular}

\section{Estimation Results}

Table 5, below, displays the marginal effects derived from multinomial logit estimates of the determinants of MSME growth in the MENA region. We consider three categories of determinants: firm characteristics, manager characteristics and environment characteristics. Innovation is one of the core factors within the first category. Results suggest that firms implementing innovations related to production activities, management practices, marketing strategy, logistics or processes increase their probability of achieving a growth rate of between $10 \%$ and $20 \%$ by about 0,0771 points. All the marginal effects associated with the innovation variable are highly significant. This positive association between innovation and firm labour growth could stem from product, process or organizational innovation, as demonstrated by previous studies. Product innovation is expected to generate positive net effects by boosting demand for the firm's products and expanding its market position (Harrison et al., 2008; Lachenmaier and Rottmann, 2011). Process innovation has a labour displacement effect in the short term, due to greater efficiency in production. This could be compensated by an increase in product demand through a reduction in production costs, implying more competitive prices. Evangelista and Vezzani (2012) give evidence that organizational change (i.e. the adoption of new business practices, knowledge management systems, etc) has an indirect positive impact on employment through the increase of sales revenues. Marketing innovation, as well as logistics 
innovation, are also considered to be important elements of non-technological innovation (Damijan et al. (2014)) that might lead to job creation via the growth of firms' sales ${ }^{6}$.

Results in table 6 also show that being a large firm reduces the probability of being a lowperforming firm in terms of labour growth, holding all other variables constant. Large and medium sized firms have more resources to invest, to innovate, to train employees and so, to expand. Using a rich panel data set of manufacturing firms in nine sub-Saharan African countries, Van Biesebroeck (2005) gives empirical evidence confirming that large and medium sized firms are expanding their workforce and their added value more rapidly than smaller firms. The age of the firm appears to be negatively related to the probability of showing high or moderate labour growth. The oldest companies develop more slowly because they have already reached their most effective operational size and their optimum productivity. Furthermore, older firms may suffer from lower growth persistence related to issues preventing their strategies to adapt to changing business conditions, as well as increasing inertia and organizational rigidities (Coad et al. 2014).

Unsurprisingly, an increase in firm sales growth rate of one percent increases the probability of being a "gazelle" by 0.05 and the probability of generating a growth rate of between $10 \%$ and $20 \%$ by 0.25 . This underlines the importance of identifying and accessing new markets.

An increase in labour productivity can reduce the probability of being a low-performing firm. However, the magnitude of the marginal effect is low.

An increase in government participation in company capital negatively affects the probability of generating a growth rate of over $10 \%$. Generally, many studies point out a negative link when investigating the impact of government involvement on company performance. This may be explained by the poor quality of management and governance in public firms.

Regarding the effect of the set of management characteristics on our dependent multinomial variable, only the owner-manager variable seems to play a statistically significant role. The owner-manager variable can decrease the probability of being a low-performing firm. Management ownership is frequently documented in the literature as being significantly and positively related to firm performance. In fact, as the proportion of shares held by the top manager increases, he is expected to be more motivated to maximize the company's interests, rather than focusing on his personal interests, (Lei and Shunlin, 2008).

Within the third set of independent variables, being located in a capital city decreases the probability of generating a growth rate below 10\%. Firms located in a capital city benefit from externalities and large scale markets. They also benefit from support programs, coaching and networking more than their counterparts located elsewhere (Liedholm 2001).

Furthermore, firms highlighting the political unrest obstacle as the biggest business constraint they face, are less likely to become "gazelles". On the other hand, firms having trouble getting a license are less likely to have a growth rate between $10 \%$ and $20 \%$. While the aforementioned constraints, especially political instability, are well emphasized in the descriptive analysis related to the four concerned MENA countries (see figure 3), it is questionable why the financial constraint does not have any statistically significant impact on the dependent multinomial variable.

${ }^{6}$ We have included a qualitative variable « Patent » taking 1 if the firm has been granted a patent during the last 3 years and 0 otherwise. However, it appears to be statistically non-significant. 
The MENA ES survey measures firms' business constraints through top managers' selfassessment of the major obstacle encountered. One might suspect numerous pitfalls in such a measurement, particularly regarding the financing constraint. Ferrando and Mulier (2013) distinguish between data on firms' perceived financing constraints and more objective data based on firms' actual applications to external financing, in order to ascertain "whether the firms that self-report to be financially constrained have different characteristics than those financially unconstrained". They find that younger firms are more likely to perceive access to finance as being complicated and to position themselves outside of the loan-application process due to "fear of rejection". Perceived financial constraints, rather than actual constraints, increase significantly when firms have more short-term debt. Further, the authors provide some evidence that firms with sufficient liquidity and lower leverage ratios are less likely to feel financially constrained. 
Table 5: Multinomial Regression Results - Marginal Effects

\begin{tabular}{|c|c|c|c|}
\hline Explanatory Variables & Growth $>=20 \%$ & $10 \%<=$ Growth $<20 \%$ & Growth $<10 \%$ \\
\hline \multicolumn{4}{|l|}{ Firm Characteristics } \\
\hline \multirow[t]{2}{*}{ Innovation } & $0.0115^{*}$ & $0.0771 * * *$ & $-0.0885 * * *$ \\
\hline & $(0.00680)$ & $(0.0174)$ & $(0.0184)$ \\
\hline \multirow[t]{2}{*}{ Sales growth rate } & $0.0499 * * *$ & $0.254 * * *$ & $-0.304 * * *$ \\
\hline & $(0.0111)$ & $(0.0518)$ & $\begin{array}{l}(0.0599) \\
\end{array}$ \\
\hline \multirow[t]{2}{*}{ Productivity $(\mathrm{t}-3)$} & $2.41 \mathrm{e}-09^{*}$ & $4.94 \mathrm{e}-09$ & $-7.35 \mathrm{e}-09$ \\
\hline & $(1.33 \mathrm{e}-09)$ & $(6.30 \mathrm{e}-09)$ & $(7.22 \mathrm{e}-09)$ \\
\hline \multirow[t]{2}{*}{ Ln (firm size) } & $0.00547 * *$ & $0.0571 * * *$ & $-0.0626 * * *$ \\
\hline & $(0.00277)$ & $(0.00612)$ & $(0.00666)$ \\
\hline \multirow[t]{2}{*}{ Ln (firm age) } & $-0.0317 * * *$ & $-0.0777 * * *$ & $0.109 * * *$ \\
\hline & $(0.00550)$ & $(0.0140)$ & $(0.0149)$ \\
\hline \multirow[t]{2}{*}{ Foreign participation } & $-4.14 \mathrm{e}-05$ & $6.15 \mathrm{e}-05$ & $-2.01 \mathrm{e}-05$ \\
\hline & $(0.000129)$ & $(0.000336)$ & $(0.000361)$ \\
\hline \multirow[t]{2}{*}{ Government participation } & $-3.12 \mathrm{e}-05$ & $-0.00367 *$ & $0.00370 *$ \\
\hline & $(0.000632)$ & $(0.00212)$ & $(0.00209)$ \\
\hline \multicolumn{4}{|l|}{ Manager characteristics } \\
\hline \multirow[t]{2}{*}{ Top manager female } & -0.00597 & 0.0119 & -0.00594 \\
\hline & $(0.0139)$ & $(0.0378)$ & $(0.0406)$ \\
\hline \multirow[t]{2}{*}{ Top manager experience } & -0.000187 & -0.000230 & 0.000417 \\
\hline & $(0.000347)$ & $(0.000816)$ & $(0.000864)$ \\
\hline \multirow[t]{2}{*}{ Owner Manager } & 0.00617 & $0.0451 * *$ & $-0.0512 * *$ \\
\hline & $(0.00779)$ & $(0.0196)$ & $(0.0210)$ \\
\hline \multicolumn{4}{|l|}{ Environment characteristics } \\
\hline \multirow[t]{2}{*}{ Licence major obstacle } & 0.00977 & $-0.0889 * *$ & 0.0791 \\
\hline & $(0.0206)$ & $(0.0444)$ & $(0.0491)$ \\
\hline \multirow[t]{2}{*}{ Finance major obstacle } & 0.00244 & 0.0257 & -0.0281 \\
\hline & $(0.0106)$ & $(0.0288)$ & $(0.0305)$ \\
\hline \multirow[t]{2}{*}{ Political instability major obstacle } & $-0.0165^{* *}$ & 0.00133 & 0.0151 \\
\hline & $(0.00731)$ & $(0.0197)$ & $(0.0207)$ \\
\hline \multirow[t]{2}{*}{ Labour inadequacy major obstacle } & 0.00144 & -0.0139 & 0.0125 \\
\hline & $\begin{array}{l}(0.0131) \\
\end{array}$ & $(0.0381)$ & $(0.0405)$ \\
\hline \multirow[t]{2}{*}{ Capital city } & $0.0162 *$ & $0.0799 * * *$ & $-0.0961 * * *$ \\
\hline & $(0.00861)$ & $(0.0206)$ & $(0.0217)$ \\
\hline
\end{tabular}

Note: Sector and country dummies are included. Number of observations: 3158 . Standard errors in parentheses ${ }^{* * *} \mathrm{p}<0.01,{ }^{* *} \mathrm{p}<0.05,{ }^{*} \mathrm{p}<0.1$ 


\section{Conclusion and Recommendations}

This study attempts to contribute to a better understanding of the main constraints and boosters for MSME growth in selected countries of the MENA region (Tunisia, Egypt, Morocco and Jordan). A multinomial logit model is used to investigate the impact of a threefold classification of firm growth determinants (company characteristics, manager characteristics and business environment characteristics). The dependent multinomial variable "growth" captures the annual average employment growth rate of MSMEs over 2009-2012.

Our findings suggest that innovation is a key factor for a firm's growth. This result is statistically robust. Innovative firms are more likely to grow. As noted above, the adoption of new technologies and processes allows the emergence of high-value added products with new markets perspectives. Therefore, the implementation of efficient and well-governed systems of innovation is a priority in the MENA region. A well-defined innovation strategy, directed to specific sectors and products, is crucial (Ghali, 2016). Greater synergy between the different actors in that process (firms, governments, research centers, agencies, etc.) is needed. Governments should play a more active role to facilitate financing of innovation, particularly in MSMEs. Innovation costs are particularly high. Additional funding and incentives are also necessary to support the innovators. It is also important to steer the efforts and incentives towards more applied research and development projects.

Further, the empirical results suggest a positive and statistically significant relationship between employment growth and firm size, once we consider the age variable. This denotes that large firms are more likely to contribute to job creation. Several studies show that large companies are also the highest performing, in terms of productivity and exports. Promoting the settlement of large companies, especially multinationals, by making sites in the MENA region more attractive is, hence, of major importance. Economic diplomacy has to play a more active role in the attraction of such companies. Political leaders are expected, inter alia to place priority on improving the business climate and removing regulatory and nonregulatory barriers.

Support the growth of small-sized firms is also vital. Specific training for managers is needed to develop strategic plans for their activities and to encourage and extend their professional network. The support structures should develop coaching led by experts and experienced business managers.

Another challenge to be highlighted: to assist small firms in identifying new markets and developing their sales which, according to our results, is one of the most important factors of firms' growth. This should be the role of professional organizations, the governmental and non-governmental structures supporting entrepreneurship and MSMEs. African markets are very promising, as they display high-growth perspectives and potentials. Companies need support to gain access to these markets, including information and experience sharing, and networking.

Finally, as noted above, the quality of the business environment is a determinant for MSME growth. According to our results, political instability seems to be a significant obstacle to firms' growth (especially in Tunisia and Egypt after the revolutions). Local firms, as well as foreign ones, need more visibility and political stability to decide whether to invest or to expand. 


\section{References}

Aghion, P., Bloom, N., Blundell, R., Griffith, R., \& Howitt, P., (2005). Competition and Innovation: an Inverted-U Relationship, The Quarterly Journal of Economics, 120, 701728.

Bianchini, S., Pellegrino, G., \& Tamagni, F., (2014). Innovation Strategies and Firm Growth: New Longitudinal Evidence from Spanish Firms, Working paper, Institute of Economics, Italy.

Coad, A., Daunfeldt, S., \& Halvarsson, D., (2014). Firm age and growth persistence Innovation Forum VI, October, November. Available at: 20140905 PARIS firm age and growth persistence.pdf (sciencesconf.org)

Damijan, J., Kostevc, C., \& Metka, S., (2014). Impact of innovation on employment and skill upgrading, Vives Discussion Paper, 44, Belgium. Available at: Innovation employment and skill upgrading_Simpatic_v3 (wordpress.com)

Doing Business Report (2017). “equal opportunity for all”, World Bank Group, 2017

Eifert, B., Gelb, A., \& Ramachandran, V., (2005). Business Environment and Comparative Advantage in Africa: Evidence from the Investment Climate Data. Working paper number 56, Center for Global Development. Available at SSRN: https://ssrn.com/abstract=1112857 or http://dx.doi.org/10.2139/ssrn.1112857

EMNES Study (2017). Micro, Small and Medium sized enterprises development in Egypt, Jordan, Morocco \& Tunisia, EMNES Studies No 3, December. Available at: emnes_study_003-msmes-development-in-the-southern-mediterranean-countries.pdf

ERF Research Report (2016). Dynamisme de la Micro et Petite Entreprise au Maroc, Research Report $n^{\circ} 0419$.

Evangelista, R., \& Vezzani, A., (2012). The impact of technological and organizational innovations on employment in European firms. Industrial and Corporate Change, Vol.21, No.4, 871-899.

Ferrando, A., and Mulier, K., (2013). Firms' Financing Constraints: Do Perceptions Match the Actual Situation? European Central Bank WP, 1577.

Hall, B., Lotti, F., \& Mairesse, J., (2008). "Employment, innovation, and productivity: evidence from Italian microdata," Industrial and Corporate Change, 17, pp 813-839.

Hampel-Milagrosa, A., Loewe, M., \& Reeg, C., (2014). Which factors determine the upgrading of small and medium-sized enterprises (SMEs)? Evidence Egypt, India and Philippines", ERF working Paper Series No 866.

Harrison, R., Jaumandreu, J., Mairesse J., \& Peters, B., (2008). Does innovation stimulate employment? A firm level analysis using comparable micro-data from four European countries, NBER Working Paper 14216, Cambridge MA: NBER. Jovanovic, B. (1982): Selection and the Evolution of Industry, Econometrica, 50, 649-670.

Lachenmaier, S., \& Rottmann, H., (2011). Effects of innovation on employment: A dynamic panel analysis, International Journal of Industrial Organization, 29(2), 210-220.

Liedholm, C., (2001). Small Firm Dynamics: Evidence from Africa and Latin America, working paper, World Bank Institute. DOI:10.1023/A:1015147826035

Lei, G., \& Shunlin, S., (2008). Management ownership and firm performance, Frontiers of business Research in China, Vol. 2(3), 372-384.

Mason, G., Bishop, K., and Robinson, C., (2009). Business growth and innovation, NESTA Research Report. Available at: business_growth_and_innovation.pdf (nesta.org.uk)

Mouelhi, R., (2015). Dynamiser la croissance des petites entreprises : Un besoin de dirigeants stratèges et développeurs, $\mathrm{N}^{\circ} 16$, May, NABES. www.nabesintl.org

Reeg, C. (2013). Micro, Small and Medium Enterprise Upgrading in Low- and Middle Income Countries - A Literature Review, Discussion Papers Bonn, Germany: German Development Institute Rothwell Roy and Dodgson Mark, External linkages and innovation in small and medium-sized enterprises $R \& D$ Management, 1991

The World Bank-Tunisia Development Policy Review (2014) The Unfinished Revolution: 
Bringing Opportunity, Good jobs and Greater Wealth to all Tunisians, Development Policy Review, Vol 1, n86179.

The World Bank (2016). European Investment Bank and European Bank for Development and Reconstruction report, What's Holding Back the Private Sector in MENA? Lessons from the Enterprise Survey.

Van Biesebroeck, J., (2005). Firm Size Matters: Growth and Productivity Growth in African Manufacturing, Economic Development and cultural change, Vol.53, No.3, 545-583 